\title{
Study on the Factors to Influence the Persistent Venture Capital for Chinese Enterprise
}

\author{
Hongxing Wen \\ Business School \\ Sichuan University \\ Chengdu, China
}

\author{
Xujun Liu \\ Business School \\ Sichuan University \\ Chengdu, China
}

\begin{abstract}
With its rich resources and a good image in the capital markets, venture capital meets the needs of many SMEs for capital and professional management personnel, so many SMEs are seeking the support of venture capital. This paper took 220 listed companies in the SME Board as research samples and analyzed the sustainable acceptance of venture capital for Chinese companies. Based on these, the paper applied the multivariate analysis method and used the proportional hazard model $(\mathrm{COX})$ and the accelerated failure model (AFT) to make discussion on the characteristics to influence SMEs in receiving venture capital. From the results, it is found that the average period to receive venture capital for Chinese companies is two to three years and the risk of companies in receiving venture capital has a trend of first fall and then rise with the increase of time, of which the large companies with a long existence have a short duration of venture capital, the companies with strong profitability have a long duration in continuously receiving venture capital, with little influence of financial liabilities changes on the persistent venture capital, and the non-high-tech enterprises have much more venture capital than the high-tech enterprises.
\end{abstract}

Keywords-Venture Capital; persistence; risk

\section{INTRODUCTION}

By the end of 2013, more than 47 million SMEs have registered in China, up to $97 \%$ of the total number of enterprises, and their contribution to gross domestic economy reached $60 \%$. The SMEs are the cradle of large enterprises, and even in the United States, $80 \%$ new technology is also created by the SMEs. However, the SMEs, especially the innovative SMEs generally have difficulty to obtain funding, so their capital is very short that has been the important reason of an innovative company to end. Therefore, the new companies have an urgent need of venture capital to sustain their business development. Venture Capital is an innovation of investment system to support business startup, it is helpful for innovative companies in solving the difficult financing and it will implement the innovative ideas and aspirations, further create greater value and wealth for the society. Venture capital is not designed for a long-term holding of venture equity, and it will provide financial support and value-added service for enterprises, and exits after the companies get mature and enter the IPO market. Therefore, the study on persistence of receiving venture capital for start-ups has a very important significance both for further grasping the current situation of Chinese start-ups and for promoting the theory of persistent venture capital for start-ups.

At present, some research has discussed the factors to influence venture capital and the investment preferences, but most of them are based on a qualitative analysis, little involved to quantitative research methods, and the research result on the risk of receiving venture capital for the companies in specific time and specific area and on the persistence of venture capital is less. Exactly what factors affect the persistence for Chinese companies to accept the venture capital? This paper took listed companies in the SME Board as research samples to study whether the Chinese companies have the behavior to persistently receive venture capital by the method of survival analysis. And thus it applied the proportional hazard model (COX) and the accelerated failure model (AFT) to make discussion on the factors of persistent venture capital respectively for the stateowned enterprises and private enterprises under the different ownership background. The results showed most of the Chinese enterprises have the period of two to three years to accept venture capital and the risk of accepting venture capital has an upward trend after drop, in which the nonhigh-tech start-up enterprises with small scale, high assets liabilities ratio and strong profitability are easier to persistently accept venture capital.

\section{LITERATURE REVIEW}

Most venture capital investors have strong strength, which not only can provide fund for startups, but also can let the startups share their market, personnel and other resources (Paul, 1998; Liu Bianye, Ning Yibo, 2015), so the startups often have a stronger motivation for support of venture capital. The venture capital enterprises will make evaluation and selection for the target enterprise after they siging contract with the startups, and then they will select the most promising companies for investment (Fried, 1998), so how to choose high-quality startups is a problem of them. Megginson (1991) and Weiss (2012) pointed out that venture capital institutions often choose the companies of good growth and good earnings for their investment. Liao (2014) et al. made analysis on the relationship between venture capital and corporate governance, and the results showed the IPO companies with support of venture capital have strong 
control power governance structure, few commission problems and little possibility of financial distress. And Liu Xing (2013) considered the high-tech enterprises at the maturity and expansion stages more easily get the support of venture capital. The venture capital is often drawn out of the capital receiving company by the mode of IPO when it has invested in the company for a period of time, so as to achieve the fund flow (Wu Jianglin, Bo Zhengcheng, Zhou Xiaohua (2011)). Shepherd and Armstrong (2004) applied empirical model to conclude that venture capitalists and entrepreneurs have divarication in the value orientation, of which venture capitalists have their investment purpose of capital appreciation, hoping a quick return for new investment so they have strong desire for short-term gain, but entrepreneurs think a lot of long-term interests. Marx (1998) and Werner (2005) made analysis on the timing of corporate exit, and then thought venture capital must have an appropriate mode of exit according to the business situation, to ensure the incentives for venture capitalists and entrepreneurs, so as to make the full investment of both have added value for the investors and the start-ups.

The above documents have important reference for further study of the paper, but there are many problems. First, the developed countries in the west usually have a clear property rights system and a mature market economy system, while China is currently in the transition of economy, and compared with foreign mature market environment, China's property rights system and the market economy system is imperfect, and then under these conditions, whether the survival conditions of Chinese enterprises and the factor impacting the persistence of corporate innovation are consistent with that in the foreign countries, still needs a verification from Chinese data. Secondly, the documents most include the research on how to choose a company for investment before venture capital is given, but little on how to attract a persist venture capital for the invested companies. Based on the proportional hazards model COX and AFT model, this paper combined the venture capital' access to the invested enterprises and the venture capital' exit from the invested company to make discussion on the risk of receiving venture capital for startups and the factors of influencing its persistence respectively from the stateowned enterprises and the private enterprises, looking forward to a theoretical basis for the investors in making optimal decision of exit.

\section{RESEARCH METHODS}

\section{A. The Measures of Persistent Venture Capital}

The time taken for an individual transforming from one state to another state in a long-term analysis is called conversion analysis or history event analysis, and also known as survival analysis in the field of biology and obsolescence Time analysis in the field of operational research. During a company receiving venture capital, the operation system of financing, investment, management and exit for venture capital decides the period of invested company receiving the venture capital. When a company transforms from a state of venture capital support into another state of no venture capital support, the survival state and survival risk of a company will. Therefore, this paper adopts proportional hazards model and accelerated failure model to make discussion on the factors of influencing the persistence of receiving venture capital, to looking forward to a realistic conclusion.

In this paper, with the length of the duration of the venture capital for a existing company as a explanatory variables, the duration of venture capital is determined according to the following method: If the company $i$ have venture capital firms in the disclosure of its top ten shareholders in the $\mathrm{t}^{\text {th }}$ year, it is proved the company received venture capital in the $\mathrm{t}^{\text {th }}$ year; if a company has had venture capital in a given $\mathrm{j}$ consecutive years, it is proved that the duration length of the company for receiving venture capital is $\mathrm{j}$ years. For instance, if the company $\mathrm{i}$ began to receive venture capital in 2007 and had been supported by the venture capital till 2014, it is proved that the duration length of the company for receiving venture capital is 8 years.

Respectively take the probability density function of the duration of receiving venture capital and the cumulative distribution functions as $\mathrm{f}(\mathrm{t})$ and $\mathrm{F}(\mathrm{t})$ :

$$
\begin{aligned}
& F(t)=P(T \leq t) \\
& f(t)=d(F(t)) / d(t)
\end{aligned}
$$

Among which, the formula (1) represents the probability of venture capital receiving during less than $t$, and for the samples in this paper is the data of 8 years from 2007 to 2014 , the $t$ value should be $1,2,3, \ldots 8$.

The "survival function" of a company in receiving venture capital is defined as the probability of venture capital receiving duration more than $\mathrm{t}$, and its expression is:

$$
S(t)=P(T>t)=1-F(t)
$$

The cumulative distribution function $F(t)$ is a monotonically increasing function, so the survival function $\mathrm{s}$ (t) is a monotonically decreasing function. The time to stop receiving the persistent venture capital is supposed as $t$, the probability to stop receiving venture capital at $(\Delta \mathrm{t}>0)$ during the period of $[t, t+\Delta t]$ is :

$$
P(t \leq T \leq t+\Delta t \mid T \geq t)=\frac{P(t \leq T \leq t+\Delta t)}{\mid P(T \geq t)}=\frac{F(t+\Delta t)-F(t)}{S(t)}
$$

\section{(4)}

After receiving venture capital for a period, the company instantly stops receiving the venture capital at $t$, for which the probability of the "risk rate" or "risk function" is defined as:

$$
\lambda(\mathrm{t})=\lim _{\Delta t \rightarrow 0} \frac{P(t \leq T \leq t+\Delta t \mid T \geq t)}{\Delta t}=\frac{1}{S(T)} \lim _{\Delta t \rightarrow 0} \frac{F(T+\Delta t)-F(t)}{\Delta t}=\frac{f(t)}{S(t)}
$$

Therefore, the risk function $\lambda(t)$ is essentially a conditional density function under the given duration of receiving venture capital $t$, also known as conditional 
mortality. in order to measure the cumulative total risk of end time $t$, the cumulative risk function is defined as:

$$
p(t)=\int_{0}^{\mu} \lambda(t) d t=-\ln S(t)
$$

Take $\mathrm{t} 1<\mathrm{t} 2<\ldots<\mathrm{tj}<\ldots<\mathrm{tk}$ as the time of a company to stop receiving venture capital, the number of individuals that still receive venture capital support but face danger in the interval[tj-1,tj]among the samples as nj, and the number of companies that stop receiving venture capital at $\mathrm{t} j$, and then $\lambda \mathrm{i}=\mathrm{mj} / \mathrm{nj}$ is the estimate of risk rate. However, this estimate is not a smooth step function, and usually the cumulative risk function should be smoothened by the kernel density method and then generate the risk function.

\section{B. The Factors to Influence the Risk Ratio and the Variables Description}

Venture capital institutions often make investment in more than one enterprise at the same time, to ensure the flow of funds, and venture capitalists will quit from the invested enterprises at the right time, while the former shareholders of the invested companies will have a certain requirements for ownership concentration to enhance the control of the company after the development to a certain extent. The above two aspects jointly determine the duration of a company to receive venture capital, therefore it is important to study the persistence of receiving venture capital.

From a practical point of view, Cumming (2011) pointed that the assets, age and brand value of the invested enterprises determine the exit way of venture capital institutions. He believed that venture capital institutions will quit from the business when the marginal cost equals to the marginal value.

With a lot of cases as analysis object, Professor Bienz (2004) set up risk model and identified the exit of venture capital at the annual meeting of European Economic Association held in Europe. Professor Bienz believed, for an enterprise with good development potential, venture capital institutions more inclined to IPO exit.

After research, Carsten Bienz (2004) showed that the best time for the exit of venture capital is related with the operating conditions of invested company, the exit deadline of venture capital and the preference of risk entrepreneurs and venture capitalists for exit way and so on. Other researchers such as Tan Yi and Feng Zongxian (2002) also believed that the operating conditions of start-ups directly determines the time of exit: If the invested company has a net asset value of considerable size and constant growth rate at a certain level, the exits of venture capital is often at the stage of price upsurge of stock market because a company listing may have a large equity appreciation by a large imaginary space, or it would not exit.

Form the statistical data of Qingke, we can find that, in 2005-2008, venture capital began to veer to online games, online video, online communities and other Internet services industries; in 2009-2011, the information transmission industry officially changed its development direction into ecommerce, including $\mathrm{B} 2 \mathrm{~B}, \mathrm{~B} 2 \mathrm{C}$, electronic payment, mobile shopping, and so on. From these, we can see that most of them choose hi-tech industry for investment and then we can infer that venture capital has more preference for high-tech industries and the investment duration for hightech industry is longer.

Based on the above theoretical analysis, we believe that the factors to influence the duration of receiving venture capital include business scale, risk rate, profitability, business life, operating conditions and whether the enterprise is a high-tech industry. Therefore, this paper selected assetliability ratio standing for the risk rate of enterprises, the ROA standing for profitability, and the financial cost rate standing for financial liabilities, and this paper classified the samples into state-owned enterprises and private enterprises, to further discuss the influence of ownership on the persistence of venture capital.

\section{EMPIRICAL ANALYSIS OF RESULTS}

\section{A. Data Sources}

This paper selected total 220 listed companies in the SME Board in 2007--2014 and screened them depending on the support of venture capital firms. The criteria of judgment is whether the words of "startup capital", "innovation investment " and " venture capital" appear in the names of the top ten shareholders when the company makes IPO, and if it contains such words, the main business should be searched through Baidu, Google and other search engines, and if the main business still contains such words, a support from startup capital firms is determined for the company in the year. When the startup capital is first invested in the company for the first time, a support of startup capital is judged for the company, and if the startup capital exits completely, a exit of startup capital is judged for the company. All the data in this paper come from GTA database and the company's annual reports, and the descriptive statistics of the samples are shown in "Table I".

TABLE I. The Descriptive StATIS TICS OF the SAMPLES IN $2007-$ 2014

\begin{tabular}{|l|l|l|l|l|}
\hline & \multicolumn{1}{|c|}{ mean } & \multicolumn{1}{c|}{ sd } & \multicolumn{1}{c|}{ max } & \multicolumn{1}{c|}{ min } \\
\hline SIZE & 21.251 & 0.951 & 25.133 & 18.592 \\
\hline DEBT & 0.429 & 0.190 & 1.292 & 0.017 \\
\hline ROA & 0.048 & 0.070 & 0.389 & 0.188 \\
\hline FER & 0.020 & 0.051 & 1.402 & 0.075 \\
\hline AGE & 4.642 & 2.596 & 11 & 0 \\
\hline TECH & 0.165 & 0.371 & 1 & 0.722 \\
\hline
\end{tabular}

\section{B. Analysis of Current Survival Status}

The survival function and risk function curves of a company receiving venture capital from 2007 to 2014 to are shown in "Fig. 1" and "Fig. 2".

From "Fig.1", we can see the survival rate falls fast in the initial years of receiving venture capital, and then falls slowly in the subsequent years. This proves that most companies have a short duration of receiving venture capital. When $\mathrm{t}=2, \quad 52.96 \%$ enterprises are still receiving venture 
capital, so most of China's listed companies have a duration of 2--3 years in receiving the venture capital; when $\mathrm{t}=8$, hardly any company has venture capital.

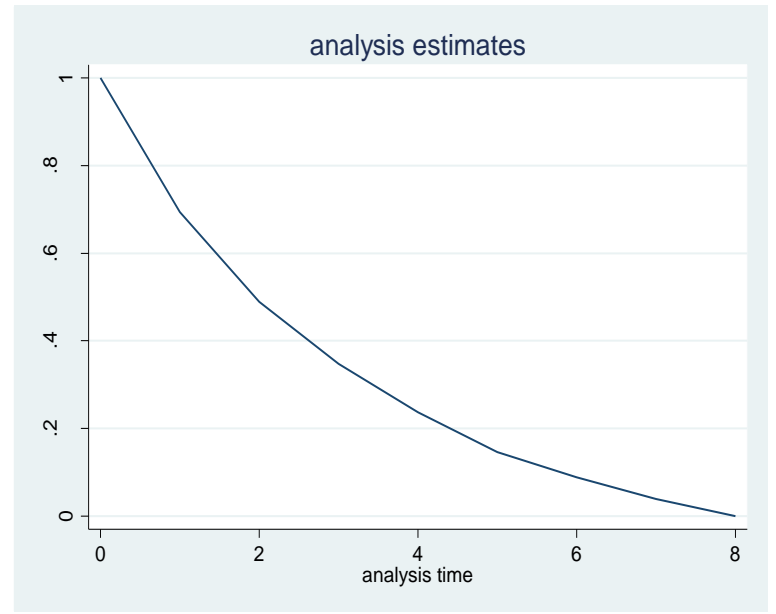

Fig. 1. Survival function curve

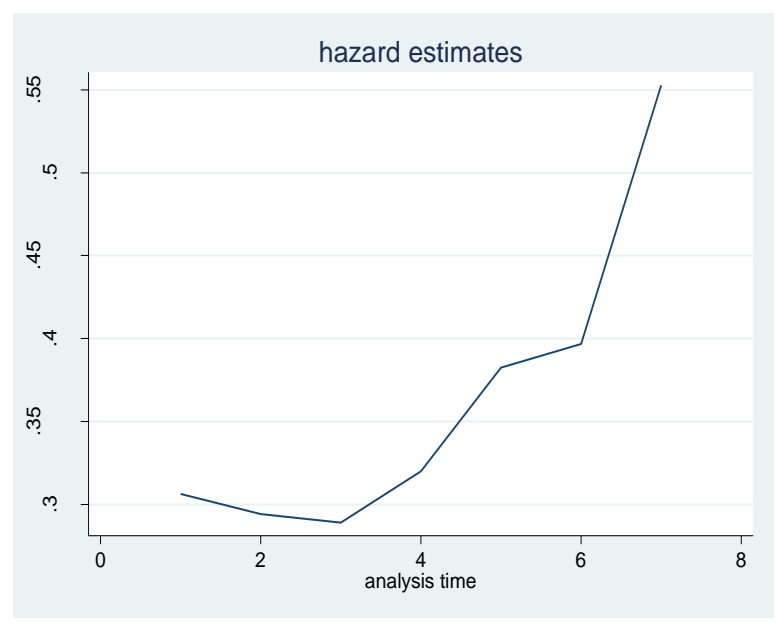

Fig. 2. Risk function curve

From "Fig. 2", we can see when a company chooses venture capital of one year, the risk rate is $30.63 \%$, and when it has the venture capital of three years, the risk rate decreases to $29.4 \%$, that is, when $\mathrm{t}<3$, the risk rate of receiving venture capital decreases gradually, but when $\mathrm{t}>3$, the risk rate rises gradually, and when $t>6$, the risk rises rapidly, when $t=8$, it reaches $70.84 \%$. This also shows that the risk is little at the early stage in persistently receiving venture capital and reaches a minimum in the third year, but with the time extension of venture capital investment, the risk increases gradually and the growth speed increases continually. This also indirectly proved that most venture capital exits from the business after a few years of investment and the companies generally have a short duration of venture capital investment in China.

\section{Analysis of Regression Results}

For a further study on the factors that affect persistent receipt of venture capital, this paper selected the firm size
(SIZE), DEBT, ROA, FER, AGE, OWN and other variables and applied COX proportional hazard model to make regression analysis for the duration of a company in receiving venture capital, in which the SIZE uses the natural logarithm of total assets as a proxy variable, and the regression results are shown below.

TABLE II. REGRESSION RESULTS OF VENTURE CAPITAL BY PROPORTIONAL HAZARDS MODEL

\begin{tabular}{|l|c|c|c|}
\hline & I & II & III \\
\hline SIZE & $0.108^{* * *}$ & & \\
& $(0.051)$ & $0.360 * * *$ & 0.025 \\
& $(0.093)$ & $(0.062)$ \\
\hline DEBT & $-0.943 * * *$ & $-1.660 * * *$ & -0.590 \\
& $(0.273)$ & $(0.474)$ & $(0.363)$ \\
\hline ROA & $-2.295 * * *$ & $-1.592^{* * *}$ & $-3.804 * * *$ \\
& $(0.876)$ & $(0.873)$ & $(1.10)$ \\
\hline FER & -0.420 & -0.452 & -2.408 \\
& $(0.325)$ & $(0.774)$ & $(3.295)$ \\
\hline AGE & $0.199 * * *$ & $0.136 * * *$ & $0.228 * * *$ \\
& $(0.021)$ & $(0.036)$ & $(0.025)$ \\
\hline TECH & $0.422^{* * *}$ & -0.205 & $0.513 * * *$ \\
& $(0.113)$ & $(0.215)$ & $(0.160)$ \\
\hline \multicolumn{2}{|c|}{ Note: $1 . * * *, * *$, respectively shows a significance under the level of $10 \%, 5 \%$ and $1 \%}$. \\
\hline
\end{tabular}

2. I, I , II respectively represents all samples, state-owned companies and private

companies.

A company's size is one of the important features of startups that will have some impact on the cooperation among enterprises. If the coefficient of the explanatory variable SIZE is positive and the significance is below the level of $1 \%$, the impact of size on receiving venture capital is negative, that is small enterprises are easier to continuously receive venture capital, because small companies are often in its primary development with short capital supply and management experiences while venture capital can give them support in capital and sources and provide a range of valueadded services. Therefore, small enterprises have stronger desires for receiving venture capital and have a longer duration. However, when all the samples are divided into state-owned enterprises and private enterprises, we can find that for state-owned enterprises, the explanatory variable SIZE has remarkable impact on the duration of venture capital, but for the private enterprise, the impact is not significant, which indicates that small state-owned enterprises are more inclined to the venture capital.

When the coefficient of explanatory variable DEBT is negative and the significance is above the level of $1 \%$, the risk of high liabilities can be reduced by introducing venture capital, and the duration of venture capital is longer. When a company has higher debt ratio, the company has a higher demand of capital especially for the SMEs in China, short capital supply and difficult financing becomes the biggest obstacle for their development. At that time, the introduction of venture capital can relax the financial needs by way of equity financing and reduce the corporate debt financing ratio so as to reducing business risk. So the companies with higher debt levels have a longer duration of venture capital. The explanatory variable DEBT is remarkable for stateowned enterprises in continuously receiving venture capital, but is not significant for the impact on private enterprise. 
This indicates that the impact of asset-liability ratio on the duration of venture capital is mainly from state-owned enterprises.

When the coefficient of ROA for corporate profitability is negative, the company has a higher earnings and a longer duration of venture capital. When a company has a good growth and profitability, the venture capital firms prefer to continue their investment in the company for more profit, while the invested company also hopes the venture capital firms continuously bring it wider market. And further promote its growth, so the companies with good profitability have a longer duration of venture capital. In addition, stateowned enterprise has a coefficient significantly greater than that of private enterprises, which indicates the ROA of stateowned enterprises has greater impact on the duration of venture capital.

When the coefficient of the explanatory variable FER is negative but neither the overall sample nor the classified sample passed the significance test, the impact of financial liabilities on the duration of venture capital is not significant. In addition, the standard deviation of private enterprises is significantly higher than that of state-owned enterprises, which shows private enterprise samples have a greater undulation.

When the coefficient of the explanatory variable AGE is positive and the significance is below the level of $1 \%$, the company has a long duration of operation, and the introduction of venture capital will increase the operation risk of the company. At this time, the company has a short duration of venture capital, because the company has formed a complete system after a period of operation and it has less need for capital and sources from the venture capital firms. Additionally, the introduction of venture capital will increase the risk of high and new technology disclosures, so the companies with a long operation period choose a short duration of venture capital. While the startups need more support from others and have more desires for the capital support, so they have a longer duration of venture capital support.

When the coefficient of the explanatory variable for high-tech enterprises (TECH) is positive and the significance is below the level of $1 \%$, the non-high-tech enterprises have a stronger persistence for introducing venture capital. hightech companies tend to focus more on the development of new technologies, and have less attention than the non-hightech enterprises on the optimization of business model, the access to social resources and the stability of earnings, etc., which is important for venture capital firms in selecting startups, so non-tech enterprises have more attraction to venture capital than high-tech companies, and have a longer duration of venture capital. But such an explanatory variable for state-owned enterprises fails the significance test.

\section{RoBUSTNESS TeST}

To test the robustness of COX proportional hazards model results, this paper further made robustness test by the accelerated failure time model (AFT). Taking proportional hazards model (COX) as the explanatory variable of the risk for continuously receiving venture capital and taking the accelerated failure model (AFT) as the explanatory variable of the average time for receiving venture capital, we found the risk is greater, the average time is less for receiving venture capital, so the regression coefficients of the above two are opposite in sign.

For the accelerated failure model (AFT), the financial expense ratio of all the samples got slightly significant from insignificance and passed the significance test for $10 \%$, and other indexes have no change in their significance and the overall result is robust. For state-owned enterprises, all indicators have passed robustness test, and for private enterprises, the significance of ROA changed into insignificance from $10 \%$. Generally speaking, all sample signs of the models in this paper have no change, significance indicators have only a little change, and the overall result is robust.

TABLE III. THE REGRESSION RESULTS OF ACCELERATED FAILURE MODEL FOR VENTURE CAPITAL (AFT)

\begin{tabular}{|l|c|c|c|}
\hline & I & II & III \\
\hline SIZE & $-0.113^{* * *}$ & $-0.247 * * *$ & 0.025 \\
& $(0.040)$ & $(0.072)$ & $(0.062)$ \\
\hline DEBT & $0.578^{* * *}$ & $1.041^{*}$ & -0.590 \\
& $(0.215)$ & $(0.410)$ & $(0.363)$ \\
\hline ROA & $2.105 * * *$ & 1.145 & $-3.804 * * *$ \\
& $(0.553)$ & $(0.891)$ & $(1.10)$ \\
\hline FER & $0.661 *$ & 0.375 & -2.408 \\
& $(0.384)$ & $(0.441)$ & $(3.295)$ \\
\hline AGE & $-0.100^{* * *}$ & $-0.073 * * *$ & $0.228 * * *$ \\
& $(0.013)$ & $(0.024)$ & $(0.025)$ \\
\hline TECH & $-0.269 * * *$ & $-0.105 * * *$ & $0.513 * * *$ \\
& $(0.096)$ & $(0.167)$ & $(0.160)$ \\
\hline \multicolumn{2}{|c|}{ Note: $1 . * * *, * * *$, respectively shows a significance under the level of $10 \%, 5 \%$ and $1 \%}$.
\end{tabular}

2. I, II, II respectively represents all samples, state-owned companies and private companies.

\section{ANALYSIS AND DISCUSSION}

This paper took 220 listed companies in the SME Board as research samples to measure the duration of the companies in receiving venture capital and studied whether the companies in China have a persistent receipt of venture capital by the method of survival analysis and further verified the factors to influence the duration of receiving venture capital by using the COX and AFT duration model .The results showed that the most Chinese SMEs received the venture capital for two to three years. When the duration is less than three years, the risk to the business is gradually decreases, when it is more than three years, the risk gradually increases, and with the growth of duration, the growth rate of risk gradually accelerates. Among them, the non-hi-tech start-ups with small scale, high liabilities and strong profitability are easier to persistently receive venture capital.

Generally, this paper from a quantitative point of view, elaborated the impact of corporate profitability, turnover capacity, size, risk level, business ownership and whether a hi-tech enterprise or not on persistent venture capital, but the further discussion is needed for some factors are not considered in this study, such as the quantified degree of data, 
the investment cycle of venture capital institutions, the relevant provisions of the state, and the degree of difficulty for listing.

\section{REFERENCES}

[1] Paul A.Gompers, JoshLemer. The determinants of corporate venture capital success: organizational structure,incentives, and eomplementarities[DB/OL].National Bureau of Economic Research. 1998

[2] Liu Bianye. To alleviate the financing bottleneck of small and medium sized enterprises of venture capital development mode of the [J]. industry economic review, 2015.5

[3] Fried V H, Bruton G D, Hisrich R D.Strategy and the board of directors in venture capital-backed firms.[J]Journal of business venturing, 1998. 13(6): 493-503.

[4] Megginson W L, Weiss K A.Venture capitalist certification in initial public offerings. The Journal of Finance, 2012,46(3): 879-903.

[5] Liao W M, Lu C C, Wang H. Venture capital,corpo-rate governance, and financial stability of IPO firms $[\mathrm{J}]$. Emerging Markets $\mathrm{R}$ eview,2014,18: 19-33.

[6] [6] Wu Jianglin, Bai Zhengcheng, Zhou Xiaohua. [J]. science and technical management from enterprise innovation and risk investment optimization, 2011.2.

[7] Shepherd D A, Armstrong M J, Lévesque M. Allocation of attention within venture capital firms [J].European Journal of Operational Research, 2005, 163(2):545-564

[8] Marx L M. Efficient venture capital financing combining debt and equity [J]. Review of Economic Design, 1998, 3(4)

[9] Neus W, Walz U. Exit timing of venture capitalists in the course of an initial public offering [J]. Journal of Financial Intermediation, 2005, 14(2):253-277

[10] Douglas Cumming, Na Dai.Fund size, limited attention and valuation of venture capital backed firms [J]Journal of Empirical Finance 2011.1

[11] Carsten Bienz. A Peeking Order of Venture Capital Exits- What Determines the Optimal Exit Channel for Venture Capital Backed Ventures?[J]. Working Paper, Goethe-University Frankfurt, 2004: 119.

[12] On the impact of venture capital on the long-term performance of Enterprises -- Based on the empirical research on the small and medium-sized enterprise board of China $[\mathrm{J}]$. Shanghai economic research, 2011.5.

[13] Chen Gongmeng [13], Yu Xin. [J] -- a comparative study of different economic impact on Chinese stock market IPO underpricing in venture capital. Xianghe Curtis, 2011 (5): 74-85.

[14] Kang Yan Hong. Optimal convertible securities and venture capital exit decision [J] Journal of Zhongnan University of Economics and Law 2006.1

[15] Jeffrey S. Petty. The Dynamics of Venture Capital Decision Making, [J] Academy of Management Annual Meeting Proceedings, 2009. 